\title{
TOWARDS LONGEVITY: MANAGING INNOVATIVENESS IN FAMILY MICRO-SMALL-MEDIUM ENTERPRISES
}

\author{
Jacob Donald Tan ${ }^{* 1}$, John Tampil Purba*), Masduki Asbari*), Agus Purwanto*) \\ ${ }^{*}$ Faculty of Economics and Business, Universitas Pelita Harapan \\ Jl. MH. Thamrin Boulevard 1100, Klp. Dua, Karawaci, Tangerang, Banten 15811, Indonesia
}

\begin{abstract}
This article explains the family and business strategies that the Micro-SmallMedium Enterprises (MSMEs) implement to dodge the ability-willingness paradox. The majority of the MSMEs in the metropolitan region of Jakarta are in their comfort zone. Only $15.90 \%$ utilize the Internet and $8.53 \%$ utilize the computer. According to the researchers' survey, most family businesses highlighted business longevity and emphasized the importance of technology and information. However, family MSMEs are still trapped in the ability-willingness paradox despite recognizing the importance of innovation. This study sampled five family MSME cases that are considered sustainable due to their innovativeness. It then investigated them by in-depth semi-structured interviews, observations, and field notes to explore how they strategize to employ innovativeness. The results signify the founders'/incumbents' receptiveness towards innovations in the business. It also signifies the stakeholders' contributive insights and the imposition of operations systemization. These findings stipulate the fundamentals for families in their MSMEs to engage in innovative activities that influence the longevity of their firms. This study concludes by recommending avenues for future research.
\end{abstract}

Keywords: family business, micro-small-medium enterprises, innovativeness, strategy, case studies

Abstrak: Artikel ini memaparkan strategi keluarga dan bisnis yang diterapkan oleh Usaha Mikro Kecil Menengah (UMKM) keluarga untuk menghindari paradoks kemampuankemauan. Mayoritas UMKM di wilayah metropolitan Jakarta berada di zona nyaman. Hanya 15,90\% yang memanfaatkan Internet dan 8,53\% yang memanfaatkan komputer. Menurut survei yang disusun oleh para peneliti, sebagian besar bisnis keluarga menyoroti umur panjang bisnis dan menekankan pentingnya teknologi dan informasi. Namun, meski menyadari pentingnya inovasi, UMKM keluarga masih terjebak dalam paradoks kemauan-kemampuan. Studi ini mengambil sampel 5 kasus UMKM keluarga yang dianggap berkelanjutan karena inovasi mereka, dan kemudian menyelidikinya dengan wawancara semi-terstruktur mendalam, observasi, dan catatan lapangan untuk mengeksplorasi bagaimana mereka menyusun strategi untuk menggunakan inovasi. Hasil tersebut menandakan penerimaan pendiri/pemegang jabatan terhadap inovasi dalam bisnis, wawasan kontributif para pemangku kepentingan, dan pengenaan sistem operasi. Temuan ini menetapkan dasar-dasar bagi keluarga di UMKM mereka untuk terlibat dalam kegiatan inovatif yang mempengaruhi umur panjang perusahaan mereka. Penelitian ini diakhiri dengan merekomendasikan jalan untuk penelitian masa depan.

Kata kunci: usaha keluarga, usaha mikro-kecil-menenga,; inovasi, strategi, studi kasus

\footnotetext{
${ }^{1}$ Corresponding author:

Email: jacob.tan@uph.edu
} 


\section{INTRODUCTION}

According to the Ministry of Communications and Informatics in Indonesia and Directorate General of Taxes (IndonesiaBaik.id, 2018), micro-small-medium enterprises (MSMEs) comprise $98.8 \%$ of all businesses contributing $60.3 \%$ to the Indonesian economy and about $97 \%$ of employment in 2018. However, even in metropolitan areas like Jakarta, most MSMEs are in their comfort zone: Only $15.90 \%$ are utilizing the Internet, and $8.53 \%$ are utilizing the computer (Bidang Neraca Wilayah dan Analisis Statistik BPS Provinsi DKI Jakarta, 2016). Additionally, most of these businesses are family-owned, as Deloitte Indonesia Country Leader Claudia Lauw mentioned that more than $95 \%$ of all businesses in Indonesia are family businesses (The Jakarta Post, 2019).

The researchers undertook a pilot study through surveys. It provides a notion that sustainability/continuity is the main concern of the founders/incumbents (Table 1). They acknowledge the critical role of technology and information in their family businesses (Table 2). This survey commenced by sending closed-ended questionnaires via email to 198 respondents, with 82 of them responding. Thus, most of them believe that technology and information play a significant role in the sustainability/continuity of their businesses. However, PricewaterhouseCoopers (PwC, 2018) indicated that to innovate to keep ahead is still one of the key issues and challenges faced by Indonesian family businesses.
This drawback is due to the ability-willingness paradox, which means that family businesses have abundant resources and abilities to innovate, but they are unwilling to do so (Belitski et al. 2021; Chrisman et al. 2015). Many research pieces focus on understanding family firm innovation in the context of the large family business, yet few on MSMEs (e.g., De Massis et al. 2016; Rondi et al. 2020). Therefore, family MSMEs' idiosyncrasy in innovation decisions has to be investigated further.

There are still ongoing tensions in the family business for the need to keep the business as is or innovate (Suddaby \& Jaskiewicz, 2020). Families tend to be risk-averse and fear wasting the resources they have accumulated over the years. Thus family firms stick to their traditional products and methods and are reluctant to grow (Lin \& Wang, 2019). Some studies describe that family businesses are less innovative than nonfamily businesses (Gómez-Mejía et al. 2011).

Some studies even denoted that family businesses could be innovative but constrained by specific aspects of the family (Alfredo De Massis et al. 2016; Duran et al. 2016; Erdogan et al. 2020). Subsequently, this leads to the premise of the ability-willingness paradox, which means the family businesses have the resources to innovate but are unwilling to innovate (Chrisman et al. 2015; De Massis et al. 2014). This paradox leads to the lack of competitive advantage of family businesses and the frustration of some family members who cannot unlock their innovation potential. Thus, this study elucidates how family businesses resolve the paradox to thrive towards innovativeness.

Table 1.The important aspects of the family business for Founders/Incumbents

Q: What important aspects do you consider having high value for your family business? Please rank them with 1 (most important) to 5 (least important)

\begin{tabular}{lccccc}
\hline & 1 & 2 & 3 & 4 & 5 \\
\hline Business growth & $20.00 \%$ & $31.43 \%$ & $34.29 \%$ & $8.57 \%$ & $5.71 \%$ \\
Business profil & $33.33 \%$ & $19.44 \%$ & $30.56 \%$ & $11.11 \%$ & $5.56 \%$ \\
Business continuity & $37.14 \%$ & $31.43 \%$ & $17.14 \%$ & $8.57 \%$ & $572 \%$ \\
Employee welfare & $2.94 \%$ & $14.71 \%$ & $8.82 \%$ & $35.29 \%$ & $38.24 \%$ \\
Brand recognition & $8.57 \%$ & $5.71 \%$ & $8.57 \%$ & $37.15 \%$ & $40.00 \%$ \\
\hline
\end{tabular}

Table 2: The importance of technology and information for Founders/Incumbents

\begin{tabular}{ccccc}
\hline Q: Do you agree that technology and information have an important role in your family business activities? \\
\hline Highly Disagree & Disagree & Neutral & Agree & Highly Agree \\
\hline $0.00 \%$ & $3.13 \%$ & $12.50 \%$ & $40.63 \%$ & $43.75 \%$ \\
\hline
\end{tabular}


Family-driven innovation focuses on the traditions and philosophies of family businesses to resolve the abilitywillingness paradox (Rondi et al. 2019; Suddaby \& Jaskiewicz, 2020). The family behaviors could provide deep insights into the family heterogeneity and their core competencies to explore and exploit innovations. Therefore, family businesses can innovate faster than non-families once they resolve to step up innovativeness (König et al. 2013). According to Duran et al. (2016), family businesses might seem to be conservative with their resources at first. They could be more efficient and effective in the innovative transformation than non-family businesses.

Hence, Barrett and Moores (2020) suggested developing further the paradox of ability vs. willingness to innovate based on paradox categories developed by Ingram et al. (2016) and Schuman et al. (2010). Both Barrett and Moores (2020) then materialized these paradox categories. They insinuated the following research questions: "What individual and firm abilities are needed to foster a willingness to innovate?" and "How do families cope with the uncertainty and time demands of innovation?". Considering the firm size of family MSMEs, the researchers in this study explore the emerging paradox that alludes to the development of innovation strategy. Furthermore, it instigated the following research questions:

1. What mindsets and strategies are required for family MSMEs to facilitate innovativeness?

2. How do their mindsets and strategies facilitate innovativeness?

\section{METHODS}

The researchers aimed to construct a conceptual contribution with an interpretative approach from primary data within about six months: in-depth semistructured interviews, observations, and field notes. Five case studies shown in Table 3 were constructed based on the MSMEs' size. The business's life span of more than 20 years indicates survivability. Moreover, the discrete industry is involved in illuminating family MSMEs' general innovativeness in Indonesia. Overall, this study proceeded for about six months (JanuaryJune, 2021), and interviews were primarily conducted online due to the pandemic.

Table 3. Profiles of Informants in Family MSMEs

\begin{tabular}{|c|c|c|c|c|c|}
\hline $\begin{array}{l}\text { Company Name } \\
\& \text { Types of Business }\end{array}$ & $\begin{array}{l}\text { Life Span } \\
\text { of Business }\end{array}$ & Name & Age & Position & Details \\
\hline \multirow[t]{3}{*}{$\begin{array}{l}\text { FLC, Timber } \\
\text { Distributor }\end{array}$} & \multirow[t]{3}{*}{32 years } & $\begin{array}{l}\text { FA, Male, Founder \& } \\
\text { Incumbent }\end{array}$ & $66-70$ & CEO & $\begin{array}{l}\text { FA worked as a foreman in a construction } \\
\text { company before starting FLC Company. }\end{array}$ \\
\hline & & $\begin{array}{l}\text { FB, Female, Founder's } \\
\text { Spouse, Co-Founder }\end{array}$ & $51-55$ & Retired & $\begin{array}{l}\text { FB owns and co-founded the company } \\
\text { together with FA. }\end{array}$ \\
\hline & & $\begin{array}{l}\text { FC, Female, 2nd } \\
\text { Generation Successor }\end{array}$ & $21-25$ & Manager & $\begin{array}{l}\text { FC is the youngest daughter and yet the } \\
\text { successor, as she had has been involved } \\
\text { daily in the business. }\end{array}$ \\
\hline \multirow[t]{3}{*}{ SHL, Fishery } & \multirow[t]{3}{*}{25 years } & $\begin{array}{l}\text { SA, Male, Founder \& } \\
\text { Incumbent }\end{array}$ & $61--65$ & Director & $\begin{array}{l}\text { SA is the founder of SHL Company, } \\
\text { currently training his successor. }\end{array}$ \\
\hline & & $\begin{array}{l}\text { SB, Female, Founder's } \\
\text { Spouse }\end{array}$ & $56-60$ & Advisor & $\begin{array}{l}\text { SB actively provides advice for issues } \\
\text { occurring in the business. }\end{array}$ \\
\hline & & $\begin{array}{l}\text { SC, Male, 2nd Generation } \\
\text { Successor }\end{array}$ & $26-30$ & Commissioner & $\begin{array}{l}\mathrm{SC} \text { is actively overseeing the governance } \\
\text { and operations of the firm and advising the } \\
\text { long-term strategies and budgetary system. }\end{array}$ \\
\hline \multirow[t]{3}{*}{$\begin{array}{l}\text { TCA, Building } \\
\text { Materials, Retail }\end{array}$} & \multirow[t]{3}{*}{21 years } & $\begin{array}{l}\text { TA, Male, Founder \& } \\
\text { Incumbent }\end{array}$ & $46--50$ & $\begin{array}{l}\text { Managing } \\
\text { Director }\end{array}$ & $\begin{array}{l}\text { TA is the founder of TCA Company. He } \\
\text { used to work for a tile retail store and then } \\
\text { set up this company with his wife and the } \\
\text { help of a close friend. }\end{array}$ \\
\hline & & $\begin{array}{l}\text { TB, Female, 2nd } \\
\text { Generation Successor }\end{array}$ & $21-25$ & Manager & $\begin{array}{l}\text { TB is the elder daughter. She is working } \\
\text { full time as the manager of the company. } \\
\text { She is passionate about the business and } \\
\text { the transgenerating the legacy of her } \\
\text { parents. }\end{array}$ \\
\hline & & $\begin{array}{l}\text { TC, Female, Key Non- } \\
\text { Family Employee }\end{array}$ & $21-25$ & Manager & $\begin{array}{l}\text { TC is an administrative staff in operations, } \\
\text { purchasing, and inventory control. She has } \\
\text { been working in the company for about } 5 \\
\text { years. }\end{array}$ \\
\hline
\end{tabular}


Table 3. Profiles of Informants in Family MSMEs (continue)

\begin{tabular}{|c|c|c|c|c|c|}
\hline $\begin{array}{l}\text { Company Name } \\
\& \text { Types of Business }\end{array}$ & $\begin{array}{l}\text { Life Span } \\
\text { of Business }\end{array}$ & Name & Age & Position & Details \\
\hline \multirow[t]{3}{*}{ VRN, Restaurant } & \multirow[t]{3}{*}{23 years } & $\begin{array}{l}\text { VA, Female, Founder's } \\
\text { Daughter, Incumbent }\end{array}$ & $41-45$ & $\begin{array}{l}\text { Managing } \\
\text { Director }\end{array}$ & $\begin{array}{l}\text { VA took over from her mother, who was } \\
\text { the founder of the restaurant after her } \\
\text { siblings were unwilling to continue the } \\
\text { business. }\end{array}$ \\
\hline & & $\begin{array}{l}\text { VB, Female, 3rd } \\
\text { Generation Successor }\end{array}$ & $16-20$ & Manager & $\begin{array}{l}\text { VB has been involved in the business, } \\
\text { helping out her mother. }\end{array}$ \\
\hline & & $\begin{array}{l}\text { VC, Female, Successor's } \\
\text { Sibling }\end{array}$ & $21-25$ & Manager & $\begin{array}{l}\mathrm{VC} \text { is currently trying out new recipe for } \\
\text { the restaurant and snack food. }\end{array}$ \\
\hline \multirow[t]{3}{*}{$\begin{array}{l}\text { XNG, } \\
\text { Tea Producer }\end{array}$} & \multirow[t]{3}{*}{20 years } & $\begin{array}{l}\text { XA, Male, Founder \& } \\
\text { Incumbent }\end{array}$ & $46-50$ & $\begin{array}{l}\text { Managing } \\
\text { Director }\end{array}$ & $\begin{array}{l}\text { XA is the founder of XNG Company. He } \\
\text { is an overseas graduate who came back to } \\
\text { set up this business. }\end{array}$ \\
\hline & & $\begin{array}{l}\text { XB, Female, Founder's } \\
\text { Spouse }\end{array}$ & $46-50$ & $\begin{array}{l}\text { Finance \& } \\
\text { Accounting } \\
\text { Manager }\end{array}$ & $\begin{array}{l}\mathrm{XB} \text { is a co-owner and oversees all the } \\
\text { finances of the company. }\end{array}$ \\
\hline & & $\begin{array}{l}\text { XC, Male, Key Non- } \\
\text { Family Employee }\end{array}$ & $51-55$ & $\begin{array}{l}\text { Regional Sales } \\
\text { Manager }\end{array}$ & $\begin{array}{l}\mathrm{XC} \text { has been working in the company } \\
\text { for about } 10 \text { years, managing sales } \\
\text { and receivables, purchase order, and } \\
\text { promotions. He had the experiences } \\
\text { working in other large companies for more } \\
\text { than } 10 \text { years. }\end{array}$ \\
\hline
\end{tabular}

The case studies represented discrete industries. First is FLC, a wholesale distribution industry. Second is SHL, considered as a fishery firm. Third is TCA, a retail industry. Forth is VRN, a food service industry. And last is XNG, a manufacturing industry. All these sampled cases or family MSMEs have a life span of 20 years or more, reflecting the firms' competitive ability. Based on Geroski (2007) survival rate, they can be considered successful. Each of the family MSME composed of 3 informants consisting of (1) the founder/incumbent, (2) one family member who is familiar with the family and business, and (3) the third could be another family member or non-family team member who is also familiar with the family and business.

From the interview data in each informant's transcript, the researchers had to translate and proceed with data reduction. Then categorizing the data, thematic analysis, and pattern coding are employed for each family MSME case. Finally, as commended by (Miles et al. 2014; Yin, 2017), a cross-case analysis is implemented (Table 4) to induce the emerging latent variables.

\section{RESULTS}

As shown in Table 4, after cross-case analysis of the five family MSMEs, the researchers were able to induce the following latent variables: Innovation receptiveness
(Variable 1), Stakeholders' contributive insights (Variable 2), and Operational systemization (Variable 3 ). These three emerging variables are required to nurture the willingness to innovate in family MSMEs.

\section{Innovation Receptiveness}

First and foremost, firm founders/incumbents must acknowledge the essential needs of innovation contributing to the firm's performance, market share, and social and environmental outcomes (Ahmad et al. 2020; Cox, 2005). This awareness triggers the vigilant search for creativity and design to achieve innovativeness in any type of innovation as illustrated by Keeley et al. (2013): profit model, network, structure, process, product performance, product system, service, channel, brand, and customer engagement. The founders/incumbents in this study understand in their minds the necessity and self-motivation to innovate in order to compete in their market segments (e.g., Octasylva et al. 2021):

At the very least, we do not just sell wood now, but also plywood, then there are materials too. So it is more of product diversification. Nevertheless, as I said, never give up. Now many are buying (from us). (FLC Founder \& Incumbent, FA)

So, from time to time, people are more modern, those who make modernization changes continue, and generations continue to do so.

(SHL Founder \& Incumbent, SA) 


\begin{tabular}{|c|c|c|c|c|c|}
\hline $\begin{array}{l}\text { Emerging } \\
\text { Latent Variables } \\
\text { in Family } \\
\text { MSME's } \\
\text { Innovativeness }\end{array}$ & Case FLC & Case SHL & Case TCA & Case VRN & Case XNG \\
\hline \multirow[t]{6}{*}{$\begin{array}{l}\text { Innovation } \\
\text { Receptiveness }\end{array}$} & $\begin{array}{l}\text { *Interpretation } \\
\text { The mindsets of the } \\
\text { family about innovating } \\
\text { business products is } \\
\text { evident. }\end{array}$ & $\begin{array}{l}\text { *Interpretation } \\
\text { The family is aware that } \\
\text { they must be open to } \\
\text { innovation. }\end{array}$ & $\begin{array}{l}\text { *Interpretation } \\
\text { The family is aware } \\
\text { of the fast-moving } \\
\text { technological era } \\
\text { to compete in the } \\
\text { marketplace. }\end{array}$ & $\begin{array}{l}\text { *Interpretation } \\
\text { The family is aware } \\
\text { of the necessity of } \\
\text { innovating to compete } \\
\text { in the market segment. }\end{array}$ & $\begin{array}{l}\text { *Interpretation } \\
\text { The family is } \\
\text { vigilant-ly looking } \\
\text { out for creative and } \\
\text { innovative ideas and } \\
\text { opportunities. }\end{array}$ \\
\hline & FA: & SA: & TA: & VA: & XA: \\
\hline & $\begin{array}{l}\text { Must be consistent, and } \\
\text { continue to be a positive } \\
\text { person. } \\
\text { At the very least, we } \\
\text { don't do not just sell } \\
\text { wood now, but also } \\
\text { plywood, then there are } \\
\text { materials too. So it's } \\
\text { it is more of a product } \\
\text { diversifica-tion. } \\
\text { But However, like I } \\
\text { said, never give up. Now } \\
\text { many are buying (from } \\
\text { us). }\end{array}$ & $\begin{array}{l}\text { So, from time to time, } \\
\text { people are more mod- } \\
\text { ern, those who make } \\
\text { modernization changes } \\
\text { continue, and generations } \\
\text { continue to do so. } \\
\text { Yes, about the spirit, we } \\
\text { have to be enthusiastic, } \\
\text { right, because with the } \\
\text { spirit, everyone can be } \\
\text { motivated and things can } \\
\text { run welleveryone can be } \\
\text { motivated and things can } \\
\text { run well with the spirit. }\end{array}$ & $\begin{array}{l}\text { It's important. Espe- } \\
\text { cially in an era like this, } \\
\text { everything is instant, } \\
\text { so it's important to } \\
\text { innovate. }\end{array}$ & $\begin{array}{l}\text { By focusing on the } \\
\text { family business that } \\
\text { we are running, we can } \\
\text { see its development as } \\
\text { well and can innovate } \\
\text { if it is necessary to } \\
\text { change. It may also be } \\
\text { necessary see outside } \\
\text { (global development) to } \\
\text { be aware of the era, so } \\
\text { that they (ideas) can be } \\
\text { applied in business. }\end{array}$ & $\begin{array}{l}\text { Making changes } \\
\text { con-tinuously, } \\
\text { of course, is the } \\
\text { competition in this } \\
\text { business world, } \\
\text { and that is getting } \\
\text { tougher. The } \\
\text { competi-tors also } \\
\text { continue to fight for } \\
\text { market share, so it is } \\
\text { also impossible for } \\
\text { us to remain silent } \\
\text { and not compete. }\end{array}$ \\
\hline & FB: & SB: & TB: & VB: & XB: \\
\hline & $\begin{array}{l}\text { Hmm, at least it's } \\
\text { product diversifica- } \\
\text { tion. We accept making } \\
\text { frames. } \\
\text { I want it to be online } \\
\text { based, so I can reach } \\
\text { more people in the } \\
\text { marketplace. }\end{array}$ & $\begin{array}{l}\text { Must be open to inno- } \\
\text { vation, yes. }\end{array}$ & $\begin{array}{l}\text { It's (The world is } \\
\text { moving) really } \\
\text { fast, especially for } \\
\text { technology, things that } \\
\text { we used to think couldn't } \\
\text { happen now have } \\
\text { become common. So } \\
\text { innova-tion is necessary, } \\
\text { yes, basically whatever } \\
\text { changes, we must be able } \\
\text { to follow as long as the } \\
\text { changes are beneficial } \\
\text { and not detrimental other } \\
\text { people. }\end{array}$ & $\begin{array}{l}\text { So, I have to focus on } \\
\text { the business family, } \\
\text { how to develop it, run } \\
\text { it, and apply innova- } \\
\text { tions. We can also see } \\
\text { examples from the } \\
\text { outside world, like what } \\
\text { innovations I can take } \\
\text { from the outside to } \\
\text { apply in my business. }\end{array}$ & $\begin{array}{l}\text { The innovations } \\
\text { have been done. } \\
\text { Before everything } \\
\text { was done by hand, } \\
\text { and a lot of human } \\
\text { labor was needed, It } \\
\text { took a long time to } \\
\text { produce. [...] From } \\
\text { there we inno-vate } \\
\text { by using ma-chines, } \\
\text { with machines that } \\
\text { work faster. }\end{array}$ \\
\hline & $\begin{array}{l}\text { FC: } \\
\text { We have to be a positive } \\
\text { and consistent person. } \\
\text { I want it to be an online- } \\
\text { based system and also to } \\
\text { reach a bigger market. }\end{array}$ & $\begin{array}{l}\text { Yes, I myself am a young } \\
\text { generation, yes, as a } \\
\text { successor, a potential } \\
\text { successor, yes, I am open } \\
\text { to innovation, and I am } \\
\text { open to inputs, because } \\
\text { without innovation we } \\
\text { cannot compete with } \\
\text { others. So I'm very open, } \\
\text { very interested. }\end{array}$ & $\begin{array}{l}{[\ldots] \text { is very important }} \\
\text { because innovation is } \\
\text { what we create some- } \\
\text { thing different from } \\
\text { our competitors. So } \\
\text { we have to innovate, } \\
\text { develop products as well } \\
\text { or develop so that our } \\
\text { company grows. }\end{array}$ & $\begin{array}{l}\text { With a focus on } \\
\text { the main business, } \\
\text { successor can provide } \\
\text { all the capabilities and } \\
\text { ideas and innovations } \\
\text { in this family business, } \\
\text { for the sake of business } \\
\text { devel-opment in the } \\
\text { long term. }\end{array}$ & $\begin{array}{l}\text { XC: } \\
\text { These employees } \\
\text { must always be } \\
\text { given trainings, } \\
\text { given directions, } \\
\text { and motivation, so } \\
\text { they have to be crea- } \\
\text { tive.... }\end{array}$ \\
\hline $\begin{array}{l}\text { Stakeholders' } \\
\text { Contribu-tive } \\
\text { Insights } \\
\text { (Employees', } \\
\text { Succes-sors', and } \\
\text { Customers') }\end{array}$ & $\begin{array}{l}\text { *Interpretation } \\
\text { The insights and } \\
\text { opinions of employees } \\
\text { is evident, but lacking } \\
\text { involving the succes- } \\
\text { sor's. The founder and } \\
\text { spouse have the final } \\
\text { call in decision-makings. }\end{array}$ & $\begin{array}{l}\text { *Interpretation } \\
\text { Founder is quite open to } \\
\text { inputs and insights from } \\
\text { the successor, but there is } \\
\text { no com-plete trust yet. }\end{array}$ & $\begin{array}{l}\text { *Interpretation } \\
\text { Founder is open to } \\
\text { suggestions from the } \\
\text { employees and his two } \\
\text { daughters. He even } \\
\text { delegates the innovative } \\
\text { initiation and activities } \\
\text { to the successor. }\end{array}$ & $\begin{array}{l}\text { *Interpretation } \\
\text { The family believes } \\
\text { that good relationship } \\
\text { is required with their } \\
\text { workers, or else } \\
\text { inno-vation will be } \\
\text { ham-pered. }\end{array}$ & $\begin{array}{l}\text { *Interpretation } \\
\text { Founder, his wife } \\
\text { (co-founder), and } \\
\text { key non-family } \\
\text { employees are } \\
\text { encouraging } \\
\text { their employees } \\
\text { to be vigi-lant in } \\
\text { providing new } \\
\text { innovative ideas } \\
\text { as benchmarking } \\
\text { strate-gies. }\end{array}$ \\
\hline
\end{tabular}




\begin{tabular}{|c|c|c|c|c|c|}
\hline \multirow[t]{2}{*}{$\begin{array}{l}\text { Emerging } \\
\text { Latent Variables } \\
\text { in Family } \\
\text { MSME's } \\
\text { Innovativeness }\end{array}$} & Case FLC & Case SHL & Case TCA & Case VRN & Case XNG \\
\hline & $\begin{array}{l}\text { FA: } \\
\text { At least I just ask their } \\
\text { opinion, what are the } \\
\text { pros and cons. The rest } \\
\text { is all in my hands the } \\
\text { decision. } \\
\text { Q: Who is the person } \\
\text { behind each innova- } \\
\text { tion? May I know? } \\
\text { A: Yes, my wife and I } \\
\text { of course... also after } \\
\text { discussing with office } \\
\text { people. }\end{array}$ & $\begin{array}{l}\text { SA: } \\
\text { Yes, we must act on } \\
\text { every decision; I must } \\
\text { approve the decision. But } \\
\text { approval by the leader } \\
\text { first. It's still not a } 100 \% \\
\text { autono-my." }\end{array}$ & $\begin{array}{l}\text { TA: } \\
\text { It's definitely a differ-ent } \\
\text { era from with (my two } \\
\text { daughters), so everything } \\
\text { is now in order (by } \\
\text { my two daughter), by } \\
\text { system. After that, we } \\
\text { don't need to be tired } \\
\text { anymore because there is } \\
\text { a system. }\end{array}$ & $\begin{array}{l}\text { VA: } \\
\text { Yes, as the owner, } \\
\text { I must have a good } \\
\text { relationship with the } \\
\text { workers because if } \\
\text { not, it can inhibit } \\
\text { innovation/new ideas. }\end{array}$ & $\begin{array}{l}\text { XA: } \\
\text { From the sales force, } \\
\text { their role will be to } \\
\text { look out for new } \\
\text { competitors in the } \\
\text { marketplace. For ex- } \\
\text { ample they would } \\
\text { say, 'As for R\&D, } \\
\text { Sir, how about we } \\
\text { try this flavor? How } \\
\text { about we change } \\
\text { the design in the } \\
\text { future like this? Or } \\
\text { the packaging is like } \\
\text { this? }\end{array}$ \\
\hline & FB: & SB: & TB: & VB: & XB: \\
\hline & $\begin{array}{l}\text { We're applying inno- } \\
\text { vation, we've got to see } \\
\text { it from the previ-ous } \\
\text { feedbacks of the } \\
\text { customers who had } \\
\text { purchased from us. } \\
{[\ldots], \text { the decision is still }} \\
100 \% \text { with us. }\end{array}$ & $\begin{array}{l}\text { Field Note (April 17, } \\
\text { 2021): } \\
\text { According to the WA } \\
\text { message, Incumbent has } \\
\text { difficulty in trust-ing } \\
\text { Successor due to lack of } \\
\text { experiences. }\end{array}$ & $\begin{array}{l}\text { Well, precisely be-cause } \\
\text { the employees here } \\
\text { haven't got the chance to } \\
\text { innovate, so I'm here as } \\
\text { the innovator. }\end{array}$ & $\begin{array}{l}\text { Of course, because in } \\
\text { any work environment, } \\
\text { the relationship } \\
\text { between employees } \\
\text { and owners must be } \\
\text { good, if for example, } \\
\text { they don't have a good } \\
\text { relationship, then the } \\
\text { communication be- } \\
\text { comes messy, they can't } \\
\text { exchange ideas, give } \\
\text { ideas and others. This } \\
\text { can hinder inno-vation. }\end{array}$ & $\begin{array}{l}\text { Inputs from } \\
\text { our em-ployees } \\
\text { are collected, } \\
\text { considered } \\
\text { and exam-ined } \\
\text { thoroughly. If for } \\
\text { example it makes } \\
\text { sense, then we will } \\
\text { proceed. }\end{array}$ \\
\hline & $\begin{array}{l}\text { FC: } \\
\text { So I cannot decide on } \\
\text { my own. Must be with } \\
\text { my parents' approval. }\end{array}$ & $\begin{array}{l}\text { SC: } \\
\text { For every action taken, } \\
\text { there must be a meeting } \\
\text { and approval from the } \\
\text { father first, so it has not } \\
\text { been fully let go. }\end{array}$ & $\begin{array}{l}\text { TC: } \\
{[\ldots] \text { for example, if we }} \\
\text { have innovative ideas, } \\
\text { we can give suggestions } \\
\text { to our owners, like } \\
\text { that..." }\end{array}$ & $\begin{array}{l}\text { VC: } \\
\text { Yes, owners and } \\
\text { suc-cessors must have } \\
\text { good relationship with } \\
\text { workers, so that they } \\
\text { can jointly develop } \\
\text { innovations. If there is } \\
\text { no good relationship, } \\
\text { innovation will be } \\
\text { hampered, of course. } \\
\text { XC: } \\
\text { Regarding employees' } \\
\text { creativity, they must } \\
\text { be smart in reading the } \\
\text { market... Competing in } \\
\text { the sense of knowing } \\
\text { what rivals are } \\
\text { currently doing. }\end{array}$ & $\begin{array}{l}\text { XC: } \\
\text { Regarding } \\
\text { employees' } \\
\text { creativity, they } \\
\text { must be smart in } \\
\text { reading the market... } \\
\text { Competing in the } \\
\text { sense of knowing } \\
\text { what rivals are } \\
\text { currently doing. }\end{array}$ \\
\hline Operational & *Interpretation & *Interpretation & *Interpretation & *Interpretation & *Interpretation \\
\hline Systemiza-tion & $\begin{array}{l}\text { Founder understands } \\
\text { the need to organize } \\
\text { to expand the business } \\
\text { market, but still } \\
\text { perplexed on how to } \\
\text { do it. Successor feels } \\
\text { the urgency to mend } \\
\text { the governance and } \\
\text { operational system of } \\
\text { the company. }\end{array}$ & $\begin{array}{l}\text { The family aligns their } \\
\text { decision-makings based } \\
\text { on the orientation of their } \\
\text { business system. }\end{array}$ & $\begin{array}{l}\text { The family makes } \\
\text { sure their business } \\
\text { system platforms such } \\
\text { as bookkeeping and } \\
\text { inventory control are } \\
\text { in order to develop } \\
\text { further in their marketing } \\
\text { activities. }\end{array}$ & $\begin{array}{l}\text { The family set a com- } \\
\text { munication practice } \\
\text { that everyone in the } \\
\text { business must be in- } \\
\text { volved. There is also a } \\
\text { financial system that the } \\
\text { founder and wife are } \\
\text { using. }\end{array}$ & $\begin{array}{l}\text { The founder and } \\
\text { key non-family } \\
\text { employee rely on } \\
\text { the established } \\
\text { management system } \\
\text { to step up their } \\
\text { innovations. }\end{array}$ \\
\hline
\end{tabular}


Table 4. Interpretative Analysis (continue)

\begin{tabular}{|c|c|c|c|c|c|}
\hline \multirow[t]{3}{*}{$\begin{array}{l}\text { Emerging } \\
\text { Latent Variables } \\
\text { in Family } \\
\text { MSME's } \\
\text { Innovativeness }\end{array}$} & Case FLC & Case SHL & Case TCA & Case VRN & Case XNG \\
\hline & FA: & SA: & TA: & VA: & XA: \\
\hline & $\begin{array}{l}\text { Must know how to } \\
\text { organize the compa-ny's } \\
\text { capacity and continue } \\
\text { to be con-sistent, don't } \\
\text { just give up and want to } \\
\text { close the business when } \\
\text { there's an obstacle. }\end{array}$ & $\begin{array}{l}\text { Every meeting I have } \\
\text { given (Successor) the } \\
\text { experiences we have } \\
\text { acquired, and our } \\
\text { company's way (sys- } \\
\text { tem). We must pass them } \\
\text { on to him. }\end{array}$ & $\begin{array}{l}\text { So everything is now in } \\
\text { order, the system. After } \\
\text { that, we don't need to be } \\
\text { tired any-more because } \\
\text { there is a system, right, } \\
\text { e-commerce also helps a } \\
\text { lot. There's a lot. }\end{array}$ & $\begin{array}{l}\text { If later I want to in- } \\
\text { form about new inno- } \\
\text { vations /ideas, it will } \\
\text { be hampered if only a } \\
\text { few people know while } \\
\text { others don't. Then the } \\
\text { situation could become } \\
\text { complicated and later } \\
\text { everyone cannot do his } \\
\text { or her job well. }\end{array}$ & $\begin{array}{l}\text { Yes, so the } \\
\text { innovation can be } \\
\text { successful because } \\
\text { the employees' } \\
\text { management system } \\
\text { is structured and } \\
\text { they understand } \\
\text { what to do. }\end{array}$ \\
\hline & \multirow[t]{2}{*}{$\begin{array}{l}\text { FB: } \\
\text { N/A }\end{array}$} & SB: & TB: & VB: & XB: \\
\hline & & $\begin{array}{l}\text { Q: Are these (family) } \\
\text { regulations brought into } \\
\text { the company's system as } \\
\text { well? } \\
\text { A: Yes }\end{array}$ & $\begin{array}{l}\text { You have to be active on } \\
\text { Instagram, Face-book, } \\
\text { Whatsapp, you have to } \\
\text { be neat, especially in the } \\
\text { service that is usually for } \\
\text { consumers to access. We } \\
\text { have to respond quickly } \\
\text { via WA, via telephone } \\
\text { like that. And also } \\
\text { updating if the goods are } \\
\text { not in the store. I try to } \\
\text { update to customers as } \\
\text { much as possible, e.g. } \\
\text { the available discounts } \\
\text { and the name of the } \\
\text { products. I have to keep } \\
\text { updating the product } \\
\text { barcodes as well. }\end{array}$ & $\begin{array}{l}\text { So when it comes to } \\
\text { operational systems, } \\
\text { my parents are still in } \\
\text { charge. Operational } \\
\text { matters such as } \\
\text { recording expenses and } \\
\text { revenues. }\end{array}$ & N/A \\
\hline & FC: & SC: & TC: & VC: & $\mathrm{XC}$ : \\
\hline & \multirow[t]{2}{*}{$\begin{array}{l}\text { I have to reorganize } \\
\text { the structure and how } \\
\text { the company runs. } \\
\text { Because if it's still } \\
\text { with a structure like } \\
\text { this, it can't outreach to } \\
\text { more people (potential } \\
\text { customers), because of } \\
\text { the existing limitations. }\end{array}$} & \multirow[t]{2}{*}{$\begin{array}{l}\text { Yes, of course } \\
\text { (Incumbent) immediately } \\
\text { gave examples of what } \\
\text { can be done and what } \\
\text { can't. Of course this is } \\
\text { based on the orientation } \\
\text { of the business system. }\end{array}$} & \multirow[t]{2}{*}{$\begin{array}{l}\text { We move from the } \\
\text { manual system to a } \\
\text { digital system. So, we } \\
\text { have used computer } \\
\text { system, and every the } \\
\text { stock inventory is clear } \\
\text { and updated. We can } \\
\text { also go online, We don't } \\
\text { use handwritten receipts, } \\
\text { but we have paper } \\
\text { receipts with codes and } \\
\text { barcodes. }\end{array}$} & \multirow[t]{2}{*}{$\begin{array}{l}\text { Every day there is } \\
\text { communication ses- } \\
\text { sion that needs to be } \\
\text { attended to address } \\
\text { issues from minor to } \\
\text { major things, so that } \\
\text { there will be no mis- } \\
\text { understanding be-tween } \\
\text { one another. }\end{array}$} & $\begin{array}{l}\text { The team provides } \\
\text { the innovated } \\
\text { product. For } \\
\text { employees, the point } \\
\text { is that from the } \\
\text { factory side, they } \\
\text { carry out based on } \\
\text { the (factory) system. } \\
\text { And there are } \\
\text { formulas they must } \\
\text { follow.... }\end{array}$ \\
\hline & & & & & $\begin{array}{l}\text { Oh, the system } \\
\text { I meant was the } \\
\text { programming } \\
\text { system in the } \\
\text { computer, which } \\
\text { is related to } \\
\text { distributions. }\end{array}$ \\
\hline
\end{tabular}

It is important. Especially in an era like this, everything is instant, and it is essential to innovate. (TCA Founder \& Incumbent, TA)

\section{By focusing on the family business that we are} running, we can see its development and innovation if it is necessary to change. It may also be necessary to see outside (global development) aware of the era so that they (ideas) can be applied in business. (VRN Incumbent, VA)
Continuing to make changes in the competition in this business world is getting tougher. The competitors also continue to fight for market share, so it is also impossible to remain silent and not compete. (XNG Founder \& Incumbent, XA)

These statements by the founders illuminated the innovative receptiveness in their mindsets. Focusing on the founders is vital because they establish longevity 
through their cultures and traditions (Suddaby \& Jaskiewicz, 2020; Tan et al. 2019). As supported by Volná et al. (2015), innovative receptiveness intrigues vision and is more likely to initiate strategic management practices to achieve the firms' goals. Thus they are in better strategic positions to gain a competitive advantage (Covin \& Miles, 1999; Lumpkin \& Dess, 1996). Hence, to summarize these findings, the researchers suggest the following proposition: Proposition 1. Founders'/ Incumbents' innovation receptiveness contributes to the success of family MSMEs' innovativeness.

\section{Stakeholders' Contributive Insights}

Baldwin and Von Hippel (2011) emphasized that innovation should shift from a company-centered attitude to an open and collaborative one. A firm in an isolated form will not sustain significantly when technological advancement diminishes the boundaries between stakeholders (Lee et al. 2012). This research shows employees' apparent contribution of innovativeness, especially in Company FLC, VRN, and XNG.

Q: Who is the person behind each innovation? May I know?

A: Yes, my wife and I, of course... also after discussing with office people.

(FLC Founder \& Incumbent, FA)

Of course, because in any work environment, the relationship between employees and owners must be good, if they do not have a good relationship, the communication becomes messy. They cannot exchange ideas, give ideas, and others. This can hinder innovation.

(VRN Successor, VB)

Inputs from our employees are collected, considered and examined thoroughly. If, for example, it makes sense, then we will proceed.

(XNG Founder's Spouse and Co-Owner, XB)

It is also plausible for Founders to delegate innovativeness to their successors, with the consciousness of their limited capability to innovate, such as in Company TCA:

It is a different era from with (my two daughters), so everything is now in order (by my two daughters), by the system.
After that, we do not need to be tired anymore because there is a system.

(TCA Founder \& Incumbent, TA)

Well, precisely because the employees here have not got the chance to innovate, I am here as the innovator. (TCA Successor, TB)

In Company XNG, the successor also often provides insights to the founder/incumbent whenever there is an opportunity to communicate with him as Father and Son:

I usually convey my ideas to my father when my father is relaxed and not busy. Usually, my father is sitting in the garden or sitting in the living room. Frequently, I convey my ideas when my father is eating.

(XNG Successor, Field Notes on April 9, 2021)

The investigation outcome from both Company FLC and SHL may suggest that the founders/incumbents are still holding tight to control their firms' management and having a trust issue with their successors:

So I cannot decide on my own. It must be with my parents'approval.

(FLC, Successor, FC)

There must be a meeting and approval from the father for every action taken, so it has not been entirely let go.

(SHL Successor, SB)

Field Note (SHL, Founder's Spouse, SC, April 17, 2021):

According to the WA message, Incumbent has difficulty trusting Successor due to lack of experience.

Trust amongst stakeholders in the company is essential to spur innovative insights and activities (Carmeli \& Spreitzer, 2009; Hattori \& Lapidus*, 2004), while especially engaging with customers inspires cocreativity and co-creation in the organization (Erhardt et al. 2019; Herrera, 2016; Parmentier \& Mangematin, 2011). However, from this study's investigation, only Company FLC is apparent in engaging customers in its innovative process:

We are applying innovation; we have got to see it from the previous feedbacks of the customers who had purchased from us.

(FLC Founder's Spouse and Co-Founder, FB) 
Thus, the outcome from the pattern analysis insinuates the lack of successors' contributive insights and customers' engagement. Both of these deficiencies may suggest the inadequate breakthrough from the abilitywillingness paradox that keeps the family MSMEs in their respective firm size. To summarize these findings, the researchers theorize the following proposition:

Proposition 2a. Employees' contributive insights contribute to the success of family MSMEs' innovativeness.

Proposition 2b. The successor's contributive insights are negatively associated with family MSMEs' innovativeness.

Proposition 2c. Customers' contributive insights are negatively associated with family MSMEs' innovativeness.

\section{Operations systemization}

Systemizing operations in firms involves setting governance to formalize their daily operations successfully (Markus \& Jacobson, 2015). Supported by Yew and Xavier (2021), organizing resources and setting daily routine operations to imprint the "how-todo" systems are pivotal for this study's family MSMEs to engage in their innovativeness:

Must know how to organize the company's capacity and continue to be consistent, do not just give up and want to close the business when there is an obstacle. (FLC, Founder \& Incumbent, FA)

I have to reorganize the structure and how the company runs. Because of the existing limitations, it cannot reach more people (potential customers) if it is still with a structure like this.

(FLC, Successor, FC)

Of course (Incumbent) immediately gave examples of what can be done and what cannot. Of course, this is based on the orientation of the business system. (SHL, Successor, SC)

We move from the manual system to a digital system. So, we have used a computer system, and every stock inventory is precise and updated. We can also go online, we do not use handwritten receipts, but we have paper receipts with codes and barcodes. (TCA, Key Non-Family Employee, TC)
The discipline to iterate the operational system in the restaurant business is evident when the successor emphasized that every team member must attend the regular meetings to provide inputs and be well informed of the upcoming changes in the business:

Every day, a communication session needs to be attended to address issues from minor to significant things so that there will be no misunderstanding between one another. (VRN, Successor's Sibling, VC)

Regarding Company XNG, since it is a teamanufacturing firm, it has set the team member system as well as the distribution system to automate most of its daily operations:

Yes, the innovation can be successful because the employees' management system is structured and understand what to do.

(XNG, Founder \& Incumbent, XA)

Oh, the system I meant was the programming system in the computer, which is related to distributions. (XNG, Key Non-Family Employee, XC)

The researchers thus derive the following proposition:

Proposition 3. Operations systemization contribute to the success of family MSME's innovativeness

\section{Managerial Implications}

Besides welcoming innovative ideas, the conceptual model can enhance innovativeness. For example, Founders or Incumbents of family SMEs can start engaging customers and successors' contributive insights to co-create products that provide a win-win situation for their firms and customers (e.g., Saragih \& Tan, 2018). Family SMEs should establish operations systemization, so theycan allocatemoretime to strategize for medium to longer term objectives, especially during this COVID-19 pandemic. For academicians, they could extend this study by employing quantitative methods to analyze how each proposition influences innovativeness.

\section{CONCLUSIONS AND RECOMMENDATIONS}

\section{Conclusions}

For the long-term sustainability of family businesses, they must be innovatively driven (Roed, 2016; Urbinati et al. 2017) and work out the ability-willingness paradox. The constructed conceptual model in Figure 


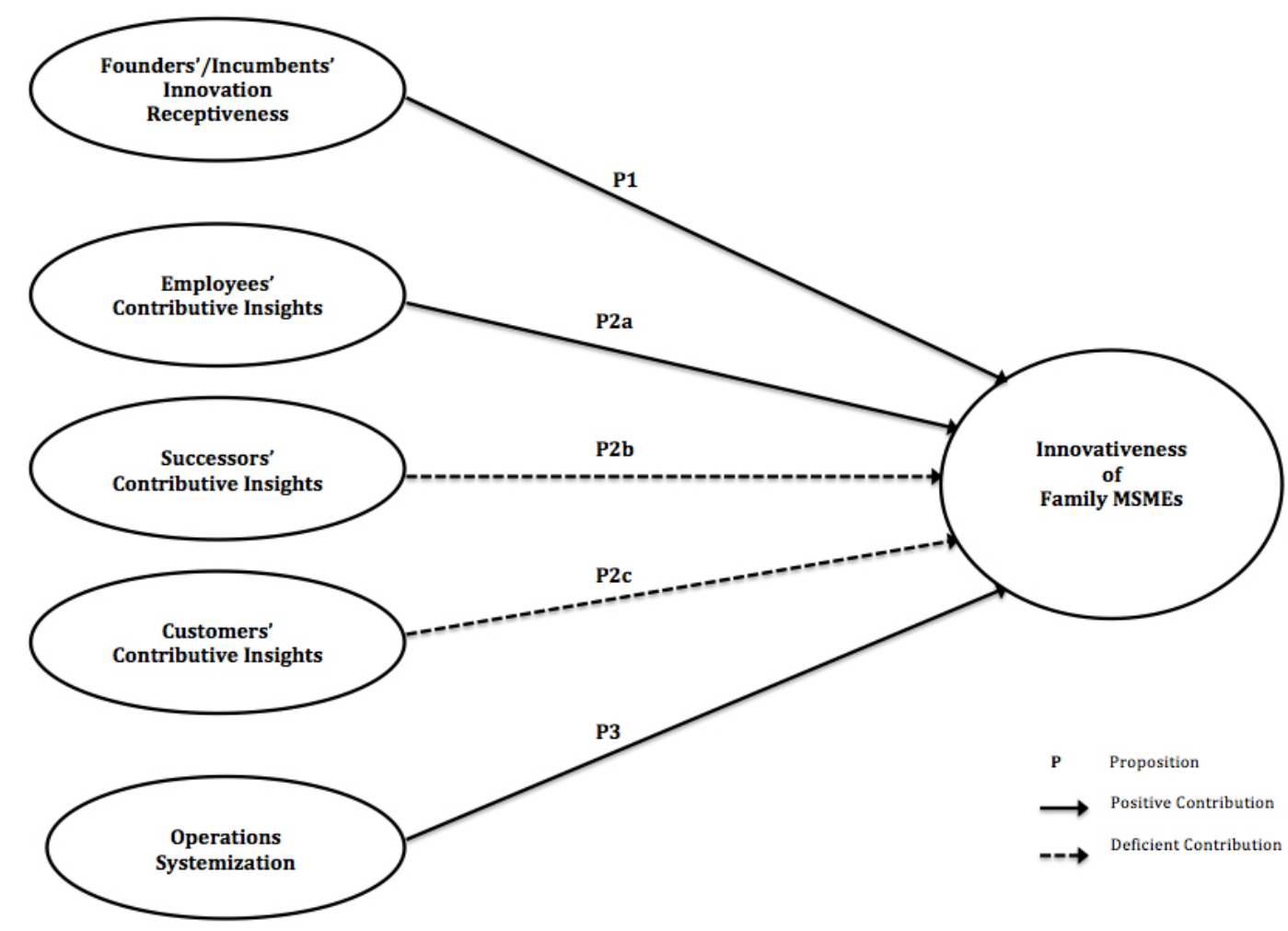

Figure 1. Constructed conceptual model

1 illuminates the mindsets and strategies to facilitate the innovativeness of family MSMEs to sustain their competitive environments.

\section{Recommendations}

This study is not without limitations. First, the sampled family MSMEs are domiciled in Indonesia, so the findings may not be generalizable to other regions. Further studies could extend to other rural regions of Indonesia or other countries. Second, except for Company XNG whose successor has not yet fully joined the family business, the sampled family cases have their successors involved in the firm for less than five years. Hence, this could explicate the deficient contribution of successors' contributive insights to innovativeness. Further study could sample successors who have been involved in their family businesses for more than five years to examine the impact of their contributive insights.

The researchers also recommend investigating a more variety of industry sectors or simply focusing on one particular industry, manufacturing or services, known as the two most popular industries that researchers scrutinize (Ortiz-Villajos \& Sotoca, 2018; Rondi et al. 2021). Further study is also encouraged to examine the dimension of trust within the family members -especially incumbent and successor- that could contribute to innovativeness. Overall, trust is the key to any relationship in family and business.

\section{ACKNOWLEDGMENTS}

We thank God and Universitas Pelita Harapan for all the support provided and also appreciate all the informants and related families that this research can be realized.

\section{REFERENCES}

Ahmad S, Omar R, Quoquab F. 2020. Family firms' sustainable longevity: The role of family involvement in business and innovation capability. Journal of Family Business Management 12(2019). https://doi.org/10.1108/ JFBM-12-2019-0081

Baldwin C, Von Hippel E. 2011. Modeling a paradigm shift: From producer innovation to user and open collaborative innovation. Organization Science 22(6):1399-1417. https://doi.org/10.1287/ orsc. 1100.0618

Barrett MA, Moores K. 2020. The what and how of Family business paradox: Literature-inspired distillations and directions. International Small Business Journal 38(3):154-183. 
Belitski M, Guenther C, KhachloufN. 2021. The AbilityWillingness Paradox of Small Family Firms to Collaborate for Innovation. Paper presented at the Academy of Management Proceedings.

Bidang Neraca Wilayah dan Analisis Statistik BPS Provinsi DKI Jakarta. 2016. Potensi Usaha Mikro Kecil In B. I. P. d. D. S. B. P. D. Jakarta (Ed.), Sensus Ekonomi 2016 Provinsi DKI Jakarta. DKI Jakarta: Badan Pusat Statistik Provinsi DKI Jakarta.

Carmeli A, Spreitzer GM. 2009. Trust, connectivity, and thriving: Implications for innovative behaviors at work. The Journal of Creative Behavior 43(3):169-191.

Chrisman JJ, Chua JH, De Massis A, Frattini F, Wright M. 2015. The ability and willingness paradox in family firm innovation. Journal of Product Innovation Management 32(3):310-318.

Covin JG, Miles MP. 1999. Corporate entrepreneurship and the pursuit of competitive advantage. Entrepreneurship Theory and Practice 23(3):4763.

Cox G. 2005. Cox Review of Creativity In Business: Building on The Uk's Strengths: TSO.

De Massis A, Frattini F, Kotlar J, Petruzzelli AM, Wright M. 2016. Innovation through tradition: Lessons from innovative family businesses and directions for future research. Academy of Management Perspectives 30(1):93-116.

De Massis A, Kotlar J, Chua JH, Chrisman JJ. 2014. Ability and willingness as sufficiency conditions for family oriented particularistic behavior: Implications for theory and empirical studies. Journal of Small Business Management 52(2):344-364.

De Massis A, Kotlar J, Frattini F, Chrisman JJ, Nordqvist M. 2016. Family governance at work: organizing for new product development in family SMEs. Family Business Review 29(2):189-213. doi:10.1177/0894486515622722

Duran P, Kammerlander N, Van Essen M, Zellweger T. 2016. Doing more with less: Innovation input and output in family firms. Academy of Management Journal 59(4):1224-1264.

Erdogan I, Rondi E, De Massis A. 2020. Managing the tradition and innovation paradox in family firms: A family imprinting perspective. Entrepreneurship Theory and Practice 44(1): 20-54.

Erhardt N, Martin-Rios C, Chan E. 2019. Value cocreation in sport entertainment between internal and external stakeholders. International Journal of Contemporary Hospitality Management

31(1):33-65.

Geroski PM JJaPP. 2007. Founding conditions and the survival of new firms. Druid Working Paper 7:711.

Gómez-Mejía LR, Hoskisson R, Makri M, Sirmon D, Campbell J.2011. Innovation and the preservation of socioemotional wealth: The paradox of $R \& D$ investment in family controlled high technology firms [unpublished manuscript). Texas: Mays Business School.

Hattori RA, Lapidus* T. 2004. Collaboration, trust and innovative change. Journal of Change Management 4(2):97-104.

Herrera MEB. 2016. Innovation for impact: Business innovation for inclusive growth. Journal of Business Research 69(5):1725-1730.

IndonesiaBaik.id. 2018. UMKM menopang ekonomi Indonesia. https://indonesiabaik.id/infografis/ umkm-menopang-ekonomi-indonesia. [23 June 2020]

Ingram AE, Lewis MW, Barton S, Gartner WB. 2016. Paradoxes and innovation in family firms: The role of paradoxical thinking. Entrepreneurship Theory and Practice 40(1):161-176. https://doi. org/10.1111/etap.12113

Keeley L, Walters H, Pikkel R, Quinn B. 2013. Ten Types of Innovation: The Discipline of Building Breakthroughs. John Wiley \& Sons.

König A, Kammerlander N, Enders A. 2013. The family innovator's dilemma: How family influence affects the adoption of discontinuous technologies by incumbent firms. Academy of management Review 38(3):418-441. https://doi. org/10.5465/amr.2011.0162

Lee SM, Olson DL, Trimi S. 2012. Co-innovation: convergenomics, collaboration, and cocreation for organizational values. Management Decision 50(5):817-831. https://doi. org/10.1108/00251741211227528

Lin WT, Wang LC. 2019. Family firms, R\&D, and internationalization: the stewardship and socioemotional wealth perspectives. Asia Pacific Journal of Management 1-29.

Lumpkin GT, Dess GG. 1996. Clarifying the entrepreneurial orientation constructandlinking it to performance. Academy of management Review 21(1):135-172. https://doi.org/10.2307/258632

Markus ML, Jacobson DD. 2015. The governance of business processes. Handbook on Business Process Management 2:311-332. 
Miles M, Huberman A, Saldaña J. 2014. Qualitative Data Analysis: A Methods Sourcebook. UK: Sage.

Octasylva ARP, Noor YL. 2021. The reasoned action approach to growth intention to increase small and medium enterprises: A conceptual framework. Indonesian Journal of Business and Entrepreneurship (IJBE) 7(3):282-282. https:// doi.org/10.17358/ijbe.7.3.282

Ortiz-Villajos JM, Sotoca S. 2018. Innovation and business survival: A long-term approach. Research Policy 47(8):1418-1436. https://doi. org/10.1016/j.respol.2018.04.019

Parmentier G, Mangematin V. 2011. Community as a locus of innovation: Co-innovation with users in the creative industries.

PwC. 2018. Family business survey: Indonesia report. https://www.pwc.com/id/en/epc/fbs-2018indonesia.pdf. [7 March 2020]

Roed I. 2016. Disentangling the family firm's innovation process: A systematic review. Journal of Family Business Strategy 7(3):185-201. https://doi. org/10.1016/j.jfbs.2016.08.004

Rondi E, De Massis A, Kotlar J. 2019. Unlocking innovation potential: A typology of family business innovation postures and the critical role of the family system. Journal of Family Business Strategy 10(4):100236.

Rondi E, De Massis A, Kraus S. 2021. Servitization through open service innovation in family firms: Exploring the ability-willingness paradox. Journal of Business Research 135:436-444. https://doi.org/10.1016/j.jbusres.2021.06.040

Rondi E, Sciascia S, De Massis AV. 2020. Innovation in small family firms. Piccola Impresa: Small Business (1):10-19. https://doi.org/10.1016/j. jfbs.2017.12.001

Saragih HS, Tan JD. 2018. Co-innovation: A review and conceptual framework. International Journal of
Business Innovation and Research 17(3):361377. https://doi.org/10.1504/IJBIR.2018.095542

Schuman A, Stutz S, Ward JL. 2010. Family Business As Paradox. New York: Springer. https://doi. org/10.1057/9780230291768

Suddaby R, Jaskiewicz P. 2020. Managing Traditions: A Critical Capability for Family Business Success. Los Angeles: SAGE Publications. https://doi. org/10.1177/0894486520942611

Tan JD, Supratikno H, Pramono R, Purba JT, Bernarto I. 2019. Nurturing transgenerational entrepreneurship in ethnic Chinese family SMEs: exploring Indonesia. Journal of Asia Business Studies 13(2):294-325. https://doi.org/10.1108/ JABS-04-2018-0132

The Jakarta Post. 2019. Only 13\% of Indonesian family businesses survive until third generation: Deloitte. https://www.thejakartapost.com/ news/2019/12/06/only-13-of-indonesianfamily-businesses-survive-until-thirdgeneration-deloitte.html

Urbinati A, Franzò S, De Massis A, Frattini F. 2017. Innovation in family firms: a review of prior studies and a framework for future research. Revolution of Innovation Management 213-246. https://doi.org/10.1057/978-1-349-95123-9_8

Volná J, Kohnová L, Bohdalová M, Holienka M. 2015. Innovative Mindset and Management Styles: An Intellectual Capital Approach. Paper presented at the International Conference on Intellectual Capital and Knowledge Management and Organisational Learning.

Yew JLK, Xavier JA. 2021. Strategizing family business with a Chandlerian perspective on 3Ms: a case study of London Biscuits Berhad in Malaysia. Journal of Asia Business Studies.

Yin RK. 2017. Case Study Research and Applications: Design and Methods. Los Angeles: SAGE publications. 